\title{
Pemberdayaan Pendidikan Islam Merespon Perkembangan Teknologi Informasi
}

\author{
Fathul Wahid
}

\begin{abstract}
Abstrak
Pendidikan Islam tidak dipungkiri memiliki peran yang penting dalam perjalanan bangsa Indonesia. Meskipun demikian, keberadaan pendidikan Islam saat ini nampaknya sudah mulai kurang menarik minat umat. Kondisi ini membutuhkan respon yang aktif-kreatif untuk memberdayakan pendidikan Islam untuk merespon perkembangan lingkungan, termasuk perkembangan teknologi informasi (TI). Tulisan ini menjelaskan potensi TI yang bisa dimanfaatkan oleh pendidikan Islam, baik sebagai lembaga pendidikan Islam maupun sebagai pengajaran Islam. Agenda aksi yang bisa dilakukan oleh pendidikan Islam untuk merespon perkembangkan TI dipresentasikan dalam akhir tulisan ini.
\end{abstract}

Kata kunci: pendidikan Islam, teknologi informasi, e-learning.

\section{A. Mendefinisikan Pendidikan Islam}

Dari berbagai literatur ditemukan bahwa terminologi "Pendidikan Islam" digunakan untuk merujuk dua hal; lembaga pendidikan Islam dan pengajaran Islam (e.g. Bawani, 2007; Zuhairini et al., 2006). Pemahanan ini penting sebelum pembahasan terkait dengan pemberdayaan pendidikan Islam dalam merespon perkembangan teknologi informasi (TI) dilakukan.

Pertama, pendidikan Islam diartikan sebagai lembaga

${ }^{1}$ Jurusan Teknik Informatika, Fakultas Teknologi Industri, Universitas Islam Indonesia. fathulwahid@fti.uii.ac.id 
pendidikan Islam. Lembaga pendidikan Islam pada awal berdirinya memang hanya mengajarkan kurikulum yang terkait dengan agama Islam, "ilmu agama" seperti syariah atau fiqih, tetapi dalam perkembangannya beberapa juga mengajarkan yang disebut "ilmu umum", mulai dari tingkat madrasah ibtidaiyah sampai dengan perguruan tinggi. Pesantren dan madrasah adalah contoh klasik lembaga pendidikan Islam yang sangat berperan sampai saat ini, bahkan mulai sebelum kelahiran Indonesia. Cikal bakal pendidikan Islam di Indonesia menurut Rahardjo (1985) sebagaimana dikutip oleh Bawani (2007) sudah ada sejak zaman awal penyebaran Islam di Indonesia oleh para wali.

Sampai saat ini, pemisahan lembaga pendidikan yang mengajarkan kedua jenis ilmu ini masih sangat kental. Padahal dalam masa perkembangan awal Islam, pemisahan ini tidak terjadi karena lembaga pendidikan Islam pada waktu itu juga menyerap pengetahuan dari dunia luar Islam seperti Yunani dan Persia (Halstead, 2004; Husain dan Ashraf, 1979; Parrinder, 1980). Tetapi saat ini, hampir di semua negara Muslim, termasuk Indonesia, terdapat dua sistem pendidikan, tradisional dan modern - yang seringkali dirujuk sebagai sekuler (Husain dan Ashraf, 1979; Parrinder, 1980; Sirozi, 2004). Dalam banyak di literatur disinyalir bahwa pemisahan ini dianggap sebagai salah satu sebab kemunduran Islam.

Kedua, terminologi Pendidikan Islam juga digunakan untuk merujuk kepada pengajaran Islam yang tidak terbatasi hanya pada lembaga pendidikan Islam saja, tetapi juga pada pendidikan "umum". Jika arti yang diambil maka pendidikan Islam mempunyai makna yang lebih luas dan universal. Husain dan Ashraf (1979:1) mendefinisikan Pendidikan Islam sebagai

"an education which trains the sensibility of pupils in such a manner that in their ... approach to all kinds of knowledge they are governed by the deeply felt ethical values of Islam. They are trained and mentally so disciplined that they want to acquire knowledge not merely to satisfy an intellectual curiosity or just for material worldly benefit but to grow up as rational, righteous beings and to bring about the spiritual, moral and physical welfare of their families, their people and mankind. Their attitude derives from a deep faith in God and a wholehearted acceptance of a God-given moral code." (dikutip dalam Halstead, 2004)

Pada Konferensi Dunia Pertama tentang Pendidikan Islam yang digelar di Mekkah pada tahun 1977, disepakati definisi umum 
pendidikan Islam, sebagai berikut.

"Pendidikan Islam adalah proses pengajaran, bimbingan, pelatihan, dan keteladanan, untuk mencapai pertumbuhan kepribadian manusia dalam semua aspeknya, baik fisik, intelektual, spiritual, imajinatif, keilmuan, bahasa, dan sebagainya, dilakukan secara individual maupun kolektif, melalui cara mendorong seseorang guna mencapai kesempuranaan, sehingga sampai pada tujuan akhir yaitu pengabdian yang sempurna kepada Allah." (dikutip dalam Bawani, 2007)

Secara umum, kedua definisi tersebut mengindikasikan bahwa yang menjadi tujuan pendidikan Islam adalah membentuk manusia sempurna (insan kamil) yang bermuara pada penghambaan kepada Allah. Dalam pendidikan Islam, tidak satu pun aspek dalam pengembangan manusia yang tidak tersentuh, mulai dari (1) membantu pengembangan individu, (2) meningkatkan pemahaman masyakarat terhadap aturan-aturan sosial dan moral, dan (3) mentransmisikan pengetahuan (Halstead, 2004). Ketiga hal ini dicapai dengan implementasi ketiga prinsip dalam pendidikan Islam, mulai dari (1) tarbiyah (to grow, increase), (2) ta'dib (to be refined, disciplined, cultured), dan (3) ta'lim (to know, be informed, perceive, discern) (Halstead, 2004).

Jika demikian halnya, maka pemisahan "ilmu agama" dan "ilmu umum" menjadi tidak relevan. Hanya saja masalahnya tidak sesederhana memisahkan air dan minyak, karena "ilmu umum" yang sekarang berkembang juga tidak lepas - atau paling tidak dicurigai bermuatan nilai Barat yang seringkali dianggap tidak sesuai dengan Islam (Dangor, 2005; Kuntowijoyo, 1994). Inilah yang kemudian menjadi landasan utama proyek Islamisasi ilmu pengetahuan yang diusung seperti oleh Isma'il al-Faruqi, Syed Husain Nasr dan Fazlur Rahman (Dangor, 2005).

Dalam tulisan ini, terminologi Pendidikan Islam merujuk kedua arti tersebut di atas sesuai dengan konteks pembahasan. Dengan demikian diharapkan diskusi terkait dengan pemberdayaan pendidikan Islam dalam merespon perkembangan TI yang diusung dapat lebih bersifat universal.

Bagian selanjutnya tulisan ini berisi dari beberapa bagian. Bagian selanjutnya akan menggambarkan secara ringkas kondisi pendidikan Islam di Indonesia. TI untuk pendidikan Islam akan didiskusikan pada bagian selanjutnya. Tulisan ini juga memberikan agenda aksi untuk memberdayakan pendidikan Islam. 


\section{B. Pendidikan Islam di Indonesia}

Pendidikan Islam telah berperan sangat penting dalam sejarah bangsa Indonesia, dan terus berkembang sampai saat ini. Meskipun demikian, keberadaan pendidikan Islam, yaitu madrasah, baru diakui statusnya oleh pemerintah pada tahun 1975 sejak diterbitkannya Surat Keputusan Bersama (SKB) Tiga Menteri. SKB ini mengakui lulusan madrasah sama dengan lulusan sekolah modern atau sekuler. Sejak saat itu, madrasah masuk dalam sistem pendidikan nasional (Zuhdi, 2006).

Pada masa awal kehadiran pendidikan Islam di Indonesia peran ulama sangat besar. Namun menurut Kuntowijoyo (2001), peran ulama yang merupakan pengawal awal pendidikan Islam di Indonesia telah bergeser mengikuti perkembangan zaman. Kuntowijoyo juga menggunakan istilah cendekiawan muslim untuk merujuk ulama dan termasuk dalam kategori ulama adalah guru. Dalam konteks perubahan sosial, perkembangan masyarakat di Indonesia dapat dikelompokkan ke dalam tiga masa: pra-industrial, semi-industrial, industrial. Namun pembagian ini nampaknya tidak mengandaikan perkembangan garis lurus. Sampai saat ini pun ketiga masyarakat tersebut masih menunjukkan eksistensinya.

Meskipun tidak secara spesifik merujuk pada pendidikan Islam, kategorisasi yang diusulkan oleh Kuntowijoyo (2001) sangat relevan untuk meneropong perkembangan pendidikan Islam, karena perkembangan pendidikan Islam di Indonesia tidak bisa lepas dari peran ulama. Pada masa pra-industrial peran ulama dalam pendidikan Islam adalah sebagai kiai dan peran yang dimainkan lebih bersifat sosial dan rekrutmen cenderung berdasar garis darah. Pada masa semi-industrial, peran ulama berubah menjadi guru dan moda komunikasi tertulis mulai dimunculkan. Peran politik ulama pada masa semi-industrial ini sangat kental dan rekrutmen bersifat segmental, dan tidak lagi berdasar garis darah.

Dalam perkembangan lebih lanjut, pada masa industrial saat ini, ulama lebih sebagai mitra dengan moda komunikasi elektronik. Peran intelektual ulama sangat menonjol dengan pola rekrutmen terbuka. Perbandingan posisi ulama dalam masyarakat pada ketiga masa ini dirangkum pada Tabel 1 . Perubahan pola hubungan ini, nampaknya secara umum juga berimbas pada ranah yang lebih luas dalam - atau harus direspon dengan aktif oleh - pendidikan Islam secara umum. 
Pemberdayaan Pendidikan Islam ... (Fathul Wahid)

Tabel 1. Pergeseran peran ulama dan hubungannya dengan masyarakat

\begin{tabular}{|l|l|l|l|l|l|l|}
\hline \multicolumn{1}{|c|}{ Masyarakat } & Ulama & \multicolumn{1}{c|}{ Peran } & Rekrutmen & Hubungan & Solidaritas & Komunikasi \\
\hline Pra-industrial & Kiai & Sosial & Geneologis & Kiai-santri & Mekanis & Lisan \\
\hline Semi-industrial & Guru & Politik & Segmental & Guru-murid & Organis & Tertulis \\
\hline Industrial & Mitra & Intelektual & Sporadis & Elite-Massa & Proliferasi & Elektronik \\
\hline
\end{tabular}

\section{Sumber: Kuntowijoyo (2001).}

Meskipun terdapat dua sistem sekolah dalam sistem pendidikan nasional, lembaga pendidikan Islam terus berkembang mengimbangi perkembangan sekolah modern/sekuler. Pada tahun 2007, menurut statistik Departemen Agama (Supriyoko, 2008), jumlah Madrasah Ibtidaiyah (MI) mencapai 23.517 lembaga, 93 persen di antaranya swasta. Jumlah Madrasah Tsanawiyah (MTs) sebanyak 12.054 lembaga, 90 persen di antaranya swasta, dan Madrasah Aliyah (MA) berjumlah 4.687 lembaga, 86 persen di antaranya swasta. Angka tersebut belum termasuk IAIN/UIN yang berjumlah 18 (www.depag. go.id) dan pesantren yang berjumlah lebih dari 16.000 (Anonim, 2008) dan madrasah diniyah.

Berdirinya MI, MTs, MA serta IAIN menunjukkan lahirnya masyarakat semi-industrial, di mana sistem sekolah telah diadopsi sebagai sistem pendidikan Islam, setelah sebelumnya dalam bentuk pesantren dan madrasah. Dalam konteks masyarakat semi-industrial yang dilanjutkan dengan industrial inilah peran teknologi, terutama TI, dalam pendidikan, termasuk pendidikan Islam perlu dipikirkan dengan lebih serius. Apalagi saat ini, diakui atau tidak, pada tataran tertentu minat umat untuk mengirim anaknya untuk mendalami Islam mulai menurun karena berbagai alasan, termasuk terkait dengan masa depan dalam mendapatkan pekerjaan.

\section{Teknologi Informasi untuk Pendidikan Islam}

Secara spesifik, belum ada studi yang dilakukan untuk melihat penerapan TI dalam lembaga pendidikan Islam, tapi beberapa studi penerapan TI telah dilakukan dalam penyebaran nilai-nilai Islam yang juga merupakan salah satu misi pendidikan Islam (e.g. Bunt, 2000; Wahid, 2004). Namun demikian, teori-teori pembelajaran secara umum nampaknya relevan untuk diterapkan pada pendidikan Islam.

Mengadopsi pemikiran Resnick (2002), ada tiga hal penting yang harus dipikirkan ulang: (1) bagaimana belajar; (2) apa yang dipelajari; 
dan (3) kapan dan dimana belajar. Dengan mencermati jawaban atas ketiga pertanyaan ini, bagaimana seharusnya pendidikan Islam diposisikan akan semakin jelas.

Pertanyaan pertama, bagaimana belajar, terkait dengan metode atau model pembelajaran. Cara berinteraksi antara guru dengan murid sangat menentukan model pembelajaran ini. Terkait dengan ini, menurut Pannen (2005), saat ini terjadi perubahan paradigma pembelajaran terkait dengan ketergantungan terhadap guru dan peran guru dalam proses pembelajaran. Proses pembelajaran seharusnya tidak $100 \%$ bergantung kepada guru lagi (instructor dependent) tetapi lebih banyak terpusat kepada murid (studentcentered learning atau instructor independent). Guru juga tidak lagi dijadikan satu-satunya rujukan semua pengetahuan tetapi lebih sebagai fasilitator atau konsultan (Resnick, 2002). Murid harus diberikan kepercayaan untuk berpendapat dan menentukan sikap. Nabi Ibrahim telah memberikan contoh dengan meminta pendapat Ismail sewaktu mendapat perintah untuk menyembelih Ismail (QS. As Shaaffaat 102). Dalam teori pendidikan modern, pendekatan ini dikenal dengan andragogi.

Intervensi yang bisa dilakukan TI dalam model pembelajaran ini sangat jelas. Hadirnya e-learning dengan semua variasi tingkatannya telah memfasilitasi perubahan ini. Secara umum, e-learning dapat didefinisikan sebagai pembelajaran yang disampaikan melalui semua media elektronik termasuk, Internet, intranet, extranet, satelit, audio/ video tape, TV interaktif, dan CD ROM (Govindasamy, 2002). Menurut Kirkpatrick (2001), e-learning telah mendorong demokratisasi pengajaran dan proses pembelajaran dengan memberikan kendali yang lebih besar dalam pembelajaran kepada murid. Hal ini sangat sesuai dengan prinsip penyelenggaraan pendidikan nasional seperti termaktub dalam Pasal 4 Undang-Undang Nomor 20 Tahun 2003 tentang Sistem Pendidikan Nasional yang menyatakan bahwa "pendidikan diselenggarakan secara demokratis dan berkeadilan serta tidak diskriminatif dengan menjunjung tinggi hak asasi manusia, nilai keagamaan, nilai kultural, dan kemajemukan bangsa".

Secara umum, intervensi e-learning dalam proses pembelajaran dapat dikelompokkan menjadi dua: komplementer dan substitusi. Yang pertama mengandaikan bahwa cara pembelajaran dengan pertemuan tatap-muka masih berjalan tetapi ditambah dengan model interaksi berbantuan TI, sedang yang kedua sebagian besar proses pembelajaran dilakukan berbantuan TI. Saat ini, regulasi yang dikeluarkan oleh pemerintah juga telah memfasilitasi pemanfaatan 
e-learning sebagai substitusi proses pembelajaran konvensional. Surat Keputusan Menteri Pendidikan Nasional No. 107/U/2001 dengan jelas membuka koridor untuk menyelenggarakan pendidikan jarak jauh di mana e-learning dapat masuk memainkan peran.

Ulasan di atas spesifik terkait dengan apa yang bisa atau seharusnya dilakukan oleh lembaga pendidikan Islam. Respon aktifkreatif terkait dengan penggunaan TI dalam proses pembelajaran akan menandakan bahwa pendidikan Islam dapat menyesuaikan diri dengan perkembangan zaman.

Dalam konteks pendidikan Islam sebagai pengajaran Islam, intervensi TI dapat maujud dalam bentuk yang lain. Isu ini terkait dengan penggunaan TI menyampaikan nilai-nilai Islam. Apa yang digambarkan oleh Bunt (Bunt, 2000) dan Wahid (2004) adalah contoh penggunaan TI, terutama Internet, dalam penyampaian nilainilai Islam melalui apa yang disebut sebagai e-dakwah.

Pertanyaan selanjutnya adalah apa yang dipelajari, seperti apakah kurikulum telah sesuai dengan kebutuhan murid dan apakah kurikulum telah dirancang untuk menyiapkan murid untuk hidup dan bekerja pada masa yang akan datang. Perkembangan TI yang sangat pesat harus dipertimbangkan dalam menjawab pertanyaanpertanyaan ini, sebab menurut Resnick (2002), selain TI akan sangat mewarnai masa depan, TI juga mengubah tidak hanya terhadap apa yang seharusnya dipelajari oleh murid, tetapi juga apa yang dapat dipelajari. Sangat mungkin banyak hal yang seharusnya atau dapat dipelajari murid tetapi tidak bisa dimasukkan ke dalam kurikulum karena "ruang" yang terbatas atau kompleksitas yang tinggi dalam mengajarkannya. Terkait dengan ini, paradigma pembelajaran yang sebelumnya mengandaikan bahwa sumberdaya pembelajaran hanya terbatas pada materi dan guru di kelas dan buku harus diubah, maka dengan hadirnya TI, terutama internet, telah menyediakan sumberdaya pembelajaran yang tidak terbatas.

Dalam konteks yang lebih luas, Kuntowijoyo (2001) mengidentifikasi lahirnya sebuah generasi Islam baru yang banyak menimba ilmu Islam dari berbagai sumber non konvensional. Kuntowijoyo (2001) merujuk generasi ini sebagai "muslim tanpa masjid." Generasi muda ini mempelajari Islam dari buku, media massa, media elektronik, dan Internet. Apa yang dipelajari dan didiskusikan pun akhirnya sangat beragam dan melampau batasbatas kurikulum yang bisa didapatkan di bangku sekolah.

Kini, sudah saatnya learning society dikampanyekan sebagai salah satu manifestasi kesadaran semangat pembelajaran sepanjang 
hayat (long-life learning). Bukankah kita tidak jarang merasa tidak tahu apa yang harus dipelajari karena tidak tersedia sarana/informasi tentang itu? Karenanya, gerakan untuk membuka akses informasi dan pengetahuan tentang Islam seluas-seluasnya kepada masyarakat menjadi sebuah keharusan. Teknologi informasi, terutama Internet, dalam hal ini memberikan peluang untuk itu.

Kapan dan dimana belajar dilakukan adalah pertanyaan ketiga yang perlu dipikirkan kembali jawabannya. Apakah pembelajaran harus dalam ruangan kelas dalam waktu tertentu atau tidak terbatas ruang dan waktu? Model pembelajaran tatap-muka yang banyak membatasi waktu dan tempat belajar. Sebagai komplemen (atau substitusi), teknologi e-learning hadir untuk memberikan kebebasan kepada murid dalam memilih tempat, waktu, dan ritme belajar (Kirkpatrick, 2001). Interaksi yang difasilitasi oleh TI ini dapat terjadi secara sinkron (pada waktu yang sama) maupun asinkron (dalam waktu yang berbeda).

E-learning dapat difasilitasi secara online maupun offline tetapi berbantuan TI. Produksi CD-ROM dengan konten materi pembelajaran termasuk di dalamnya. Kini, kita bisa dapatkan banyak CD-ROM untuk pembelajaran di pasaran; bahkan mulai untuk balita, bahkan beberapa CD-ROM telah memfasilitasi murid belajar sesuai dengan kurikulum yang sedang berjalan dengan kemasan yang menarik. Dalam hal ini, TI dapat menghadirkan digital excitement dalam proses pembelajaran, sehingga proses pembelajaran menjadi lebih menarik.

Untuk menfasilitasi e-learning dengan bantuan koneksi Internet, dalam beberapa tahun terakhir, telah dikembangkan banyak aplikasi yang dirancang untuk mendukung proses pembelajaran. Aplikasi ini sering disebut dengan Learning Management System (LMS). LMS ini mengintegrasikan banyak fungsi yang mendukung proses pembelajaran seperti menfasilitasi berbagai macam bentuk materi instruksional (teks, audio, video), e-mail, chat, diskusi online, forum, kuis, dan penugasan. Beberapa contoh LMS adalah WebCT (www. webct.com), Blackboard (www.blackboard. com), Macromedia Breeze (www.macromedia.com/oftware/breeze/), dan Fronter (www.fronter. no). LMS sudah banyak diadopsi oleh banyak lembaga pendidikan di dunia.

Banyak kritik dialamatkan kepada penggunaan LMS yang dianggap tidak mempertimbangkan aspek pedagogis. Karenanya, menurut Institute for Higher Education Policy, Amerika (dalam Govindasamy, 2002) terdapat tujuh parameter yang perlu 
diperhatikan dalam menerapkan e-learning yang mempertimbangkan prinsip-prinsip pedagogis, yaitu: (1) institutional support; (2) course development; (3) teaching and learning; (4) course structure; (5) student support; (6) faculty support; dan (7) evaluation and assessment. Dalam bahasa lain, Soekartawi (2003) mengidentifikasi keberhasilan implementasi e-learning sangat tergantung kepada penilaian apakah: (a) e-learning itu sudah menjadikan suatu kebutuhan; (b) tersedianya infrastruktur pendukung seperti telepon dan listrik (c) tersedianya fasilitas jaringan dan koneksi Internet; (d) software pembelajaran (learning management system); (e) kemampuan dan ketrampilan orang yang mengoperasikannya; dan (f) kebijakan yang mendukung pelaksanaan program e-learning.

Dalam konteks yang lebih luas, yaitu dalam manajemen dunia pendidikan, berdasar studi tentang tujuan pemanfaatan TI di dunia pendidikan terkemuka di Amerika, Alavi dan Gallupe (2003) menemukan beberapa tujuan pemanfaatan TI, yaitu (1) memperbaiki competitive positioning; (2) meningkatkan brand image; (3) meningkatkan kualitas pembelajaran dan pengajaran; (4) meningkatkan kepuasan murid; (5) meningkatkan pendapatan; (6) memperluas basis murid; (7) meningkatkan kualitas pelayanan; (8) mengurangi biaya operasi; dan (9) mengembangkan produk dan layanan baru.

Di luar batas-batas lembaga pendidikan Islam, pendidikan Islam sebagai pembelajaran Islam harusnya menjadi sebuah kesadaran bersama untuk meningkatkan kualitas diri dalam bingkai pengabdian kepada Allah. TI dapat memfasilitasi pendidikan Islam melampaui batas ruang dan waktu. Sebagai contoh, jika dulu seseorang untuk mencari salah satu ayat berdasar potongan ayat dalam Al-Quran harus dengan lincah mencarinya dalam Kitab Fathurrahman yang sangat tebal itu, saat ini dengan software yang diinstal dalam komputer atau PDA, atau bahkan telepon seluler, hal yang sama dapat dilakukan dengan jauh lebih mudah dengan variasi yang tanpa batas. Al-Quran, Hadits, serta literatur klasik Islam dalam diakses dalam bentuk digital yang dapat diakses dengan mudah. Intinya, kehadiran TI telah menjanjikan perubahan proses pembelajaran yang lebih menarik, mudah, dan berkualitas.

\section{Agenda Aksi}

Kini sudah saatnya pendidikan Islam merespon perkembangan TI dengan bijak, sebab potensi TI seperti yang telah dibahas di atas 
dapat memainkan peran dalam pencapaian tujuan pendidikan Islam yang sangat mulia. Ada beberapa agenda aksi yang bisa diusulkan untuk dilakukan dalam mencapai tujuan tersebut, yaitu:

Pertama, pemahaman adanya pemisahan antara "ilmu umum" dan "ilmu agama" di kalangan perlu dipikirkan ulang. Apa yang dikemukakan oleh Al-Ghazali dalam Ihya'u Ulumuddin yang memisahkan ilmu berdasar kewajiban dalam mempelajarinya dapat dijadikan titik awal. "Ilmu agama" wajib ain dipelajari oleh semua muslim, sedang "ilmu umum" dimasukkan ke dalam ilmu yang wajib kifayah untuk dipelajari. Dengan demikian, kalau pun harus fokus dalam mempelajari "ilmu agama", tidak lantas menyalahkan atau - paling tidak - menganggap rendah komitmen keislaman orang mempelajari "ilmu umum". Tentu saja hal ini harus diimbangi dengan mempelajari "ilmu agama" sampai pada tingkatan tertentu, sehingga tujuan pendidikan Islam yang membingkai setiap ilmu dan pengamalannya dalam semangat pengabdian kepada Allah tetap terjaga. Dalam beberapa kasus, "ilmu umum" memang perlu dikaji ulang pada tingkat epistemologis, seperti ekonomi dan psikologi, sedang "ilmu umum" yang lain, seperti teknik, cukup sampai pada tataran aksiologis.

Kedua, pada tataran yang lebih praktis, perlu pengenalan TI secara lebih terstruktur dalam kurikulum lembaga pendidikan Islam. Hal ini dilakukan dengan didasarkan pada kesadaran akan potensi TI dalam mendukung pendidikan Islam dalam mencapai tujuannya. Kurikulum memang seharusnya merupakan respon terhadap perkembangan dalam masyarakat, termasuk hadirnya TI. Kliebard (1992:158) sebagai dikutip oleh Zuhdi (2006) menyatakan "the relationship between a society and curriculum is reciprocal".

Ketiga, TI sudah saatnya juga dimasukkan ke dalam konteks proses pembelajaran dan manajemen lembaga pendidikan Islam. Dengan demikian, diharapkan proses transformasi ilmu dan nilai dapat berlangsung dengan lebih menarik dan lembaga pendidikan Islam dikelola dengan lebih baik. Prinsip dan teknologi e-learning, termasuk pengembangan konten sudah seharusnya dipikirkan dengan lebih serius. Hal ini hanya bisa dilakukan jika terjadi kerjasama sinergis antara ahli pendidikan Islam dan ahli TI. Ini juga sebagai respon terhadap perubahan masyarakat yang dikategorikan oleh Kuntowijoyo (2001) sebagai masa industrial.

Tentu saja perlu dicatat di sini bahwa TI tidak hadir menggantikan metode konvensional, tetapi lebih sebagai pelengkap. Dengan demikian, ketiga prinsip pendidikan Islam, tarbiyah, ta'dib, dan ta'lim tetap terjaga. 
Keempat, dalam konteks yang lebih luas, pendidikan Islam sebagai pengajaran Islam, perlu diwujudkan dalam bentuk akses umat yang seluas-luasnya, terutama kepada "ilmu agama", menggunakan TI, terutama Internet. Dengan demikian, penyampaian "ilmu agama" dan nilai-nilai yang menyertainya akan melampaui batas-batas ruang dan waktu, di samping dapat menghadirkan Islam apa adanya kepada semua pihak (Wahid, 2004). Hal ini juga dapat dijadikan salah satu senjata dalam perang media yang seringkali menempatkan Islam dalam posisi yang tidak diuntungkan (Said, 1981).

\section{DAFTAR PUSTAKA}

Alavi, M., dan Gallupe, R. B. (2003). Using Information Technology in Learning: Case Studies in Business and Management Education Programs. Academy of Management Learning and Education, 2(2), 139-153.

Anonim. (2008). Pembiayaan dan Data Usaha Pesantren di Indonesia. Diakses pada 9 Juni 2008 dari http://dedenfaoz.wordpress. com/2008/01/03/jenis-usaha-pesantren-dan-kendala-pengembangan-ekonomipesantren/

Bawani, I. (2007). Eksistensi Pendidikan Islam pada Era Otonomi Daerah. Tsaqafah, 2(1), 53-73.

Bunt, G. (2000). Virtually Islamic: Computer-mediated Communication and Cyber Islamic Environments. Cardiff: University of Wales Press.

Dangor, S. (2005). Islamization of Disciplines: Towards an Indigenous Educational System. Educational Philosophy and Theory, 37(4), 519-531.

Govindasamy, T. (2002). Successful Implementation of e-Learning: Pedagogical Considerations. Internet and Higher Education, 4, 287-299.

Halstead, J. M. (2004). An Islamic Concept of Education. Comparative Education, 4O(4), 517-529.

Husain, S. S., dan Ashraf, S. A. (1979). Crisis in Muslim Education. London: Hodder \& Stoughton.

Kirkpatrick, D. (2001). Who Owns the Curriculum? Dalam B. Brook $\&$ A. Gilding (Eds.), The Ethics and Equity of e-Learning in Higher Education (pp. 41-48). Melbourne: Equity and Social Justice, Victoria University. 
Kliebard, H. M. (1992). Constructing a History of the American Curriculum. Dalam P. W. Jackson (Ed.), Handbook of Research on Curriculum (pp. 157-184). New York: Macmillan.

Kuntowijoyo. (1994). Dinamika Sejarah Umat Islam Indonesia. Yogyakarta: Shalahuddin Press dan Pustaka Pelajar.

Kuntowijoyo. (2001). Muslim Tanpa Masjid. Bandung: Mizan.

Pannen, P. (2005). Pemanfaatan ICT dalam Pembelajaran. Makalah dipresentasikan pada Seminar Sun Commitment in Education and Research Industry, Jakarta, 29 Juni.

Parrinder, G. (1980). Review on Crisis in Muslim Education by S. S. Husain ; S. A. Ashraf and Aims and Objectives of Islamic Education by S. N. Al-Attas. Comparative Education, 16(2), 206207.

Rahardjo, M. D. (Ed.). (1985). Pergulatan Dunia Pesantren. Jakarta: P3M.

Resnick, M. (2002). Rethinking Learning in the Digital Age. Dalam G. Kirkman, P. K. Cornelius, G. Kirkman, J. D. Sachs \& P. K. Cornelius (Eds.), The Global Information Technology Report 20012002: Readiness for the Networked World. New York: Oxford University Press, USA.

Said, E. W. (1981). Covering Islam: How the Media and the Experts Determine How We See Rest of the World. London: Routledge \& Kegan Paul.

Sirozi, M. (2004). Secular-Religious Debates on Indonesian National Education System: Colonial Legacy and a Search for National Identity in Education. Intercultural Education, 15(2), 123-137.

Soekartawi. (2003). E-Learning di Indonesia dan Prospeknya di Masa Mendatang. Makalah dipresentasikan pada Presentasi pada Seminar e-Learning perlu e-Library, Universitas Petra, Surabaya, 3 Februari.

Supriyoko, K. (2008). Problema Besar Madrasah. Republika.

Wahid, F. (2004). E-Dakwah: Dakwah Melalui Internet. Yogyakarta: Gava Media.

Zuhairini, Kasiram, M., Ghofir, A., Tadjab, Fadjar, M., dan Umar, M. (2006). Sejarah Pendidikan Islam. Jakarta: Bumi Aksara dan Departemen Agama RI.

Zuhdi, M. (2006). Modernization of Indonesian Islamic Schools' Curricula, 1945-2003. International Journal of Inclusive Education, 10(4-5), 415-427. 